\title{
Foreword to Special Issue: Festschrift in honour of Emeritus Professor Alfred Susu
}

\author{
Adesoji Adesina $^{1}$
}

Published online: 26 November 2018

(c) The Author(s) 2018

This Special Issue of Applied Petrochemical Research focussing on refining catalysis and petrochemical processes celebrates the outstanding research career of Professor Alfred Susu in the field, especially his pioneering work in Nigeria. Professor Susu received his chemical engineering education in the USA having obtained a PhD from Stanford University in 1970 under the supervision of Professor Robert J. Madix. After serving briefly as an Assistant Professor at the University of Notre Dame, IN, USA, he returned to the University of Ife, Nigeria, subsequently moving to the University of Lagos as one of the founding chemical engineering faculty in 1973. Over the next four decades, he established a strong tradition of catalysis research that brought international focus to the institution and an excellent industrial partnership with the Nigerian petroleum and gas processing industries. In addition to being a prolific scholar (hundreds of refereed publications and several patents), he supervised many doctoral and Master's research students to completion-some of whom are now captains of the national oil and gas processing sector. He is a major inspiration to the development of chemical engineering education in Nigeria and the growth of the profession as an enviable engineering discipline. He is a leading consultant to government and industry. Moreover, Professor Susu has carried out extensive interdisciplinary research with significant impact in the fields of industrial safety, risk analysis and management, pharmaceutical sciences and medicine. In recognition of his outstanding scholarship and versatility, the Federal Government awarded him the highest national honours reserved only for distinguished academics, the Nigerian National Order of Merit, in 2003. $\mathrm{He}$ is also a recipient of other national and international awards from various professional bodies.

Even after retirement, Professor Susu remains eminently prodigious, mentoring and challenging the next generation of researchers to greater heights of accomplishments. It is with a deep sense of gratitude and collective enthusiasm that the contributors of this Special Issue (who constitute only a fractional representation of all who draw their professional and academic lineage from him) join in the celebration of his 78th birth-year anniversary. We truly wish him many more years of healthy living and service to the chemical engineering community in Nigeria and the world at large.

Adesoji Adesina

Guest Editor

Publisher's Note Springer Nature remains neutral with regard to jurisdictional claims in published maps and institutional affiliations.

Open Access This article is distributed under the terms of the Creative Commons Attribution 4.0 International License (http://creativeco mmons.org/licenses/by/4.0/), which permits unrestricted use, distribution, and reproduction in any medium, provided you give appropriate credit to the original author(s) and the source, provide a link to the Creative Commons license, and indicate if changes were made.
Adesoji Adesina

ceo@atodatech.com

1 ATODATECH LLC, Pasadena, CA 91101, USA 